九州大学学術情報リポジトリ

Kyushu University Institutional Repository

\title{
THE FAMILY ANTHRIBIDAE OFJAPAN (COLEOPTERA). PART 2"
}

Morimoto, Katsura

Entomological Laboratory, Faculty of Agriculture, Kyushu University

https://doi.org/10.5109/2387

出版情報: ESAKIA. 14, pp.1-23，1979-11-15. Entomological Laboratory, Faculty of Agriculture, Kyushu University

バージョン :

権利関係 : 
THE FAMILY ANTHRIBIDAE OF JAPAN (COLEOPTERA). PART 2*

\author{
K A TSURA M ORIMOTO \\ Entomological Laboratory, Faculty of Agriculture \\ Kyushu University, Fukuoka 812, Japan
}

\begin{abstract}
This is the second part of the revision of Japanese Anthribidae, treating the tribes Platystomini, Mecocerini, Xylinadini and Ecelonerini.

New taxa, recombinations and synonymies treated in this paper are as follows :

Penestica brevis (Jordan, 1912), comb. nov. (Paraphloeobius)

Caenophloeobius gen. nov. (type : Phloeomimus inconspicuus Wolfrum, 1948)

Caenophloeobius inconspicuus (Wolfrum, 1948), comb. nov. (Phloeomimus)

Phloeobius planus Shibata, 1963

= Caenophloeobius inconspicuus (Wolfrum, 1948), syn. nov.

Caenophloeobius tenuipes (Jordan, 1936), comb. nov. (Phloeomimus)

Caenophloeobius facilis (Jordan, 1931), comb. nov. (Phloeobius)

Phloeobius stenoides Shibata, 1963

= Phloeobius stenus Jordan, 1923, syn. nov.

Mecotropis ogasawarai $\mathrm{sp} . \mathrm{n}$ ov.

Xylinada oshimai sp. nov.

Eucorynus flavescens Nakane, 1963

= Rawasia ritsemae Roelofs, 1880, syn. nov.

Dendrotrogus japonicus sp. $\mathrm{n}$ ov.

Dendrotrogus nagaoi $\mathrm{sp}$. nov.

Xylinada striatifrons Jordan, 1895, is recorded from Japan for the first time.
\end{abstract}

Tribe P LATYSTOMINI

Anthribides vrais Lacordaire, Gen. Col. VII: 573, 1866.

Platystomini Valentine, Tans. Amer. Ent. Soc. LXXXVI: 48, 1960.

\title{
Exillis Pascoe
}

Exillis Pascoe, Ann. Mag. Nat. Hist. (3) V: 43, 1860 (Type :Exillis longicornis Pascoe, 1860, by monotypy).

Exillis japonicola Nakane (Fig. 1)

Exillis japonicola Nakane, Fragm. Col., pars 8: 32, 1963 (Kochi: Okinoshima ; Kagoshima :

* Contribution from the Entomological Laboratory, Faculty of Agriculture, Kyushu University, Fukuoka (Ser. 3, No. 60). 
Sata); Nakane, Icon. Ins. Jap. Col. Nat. Ed., II : 351, pl. 176, f. 5, 1963 (Shikoku, Kyushu).

Specimens examined :750 exs. from Is. Hachijo, Kochi (Ashizuri), Fukuoka (Mt. Hiko, Mt. Fukuchi), Kagoshima (Cape Sata), Is. Yaku, Is. Kuchinoshima, Is. Takarashima, Is. Kotakarashima, Is. Amami-Oshima, Is. Okinoerabu, Is. Okinawa, Is. Ishigaki, Is. Iriomote, Is. Yonaguni, and Taiwan (Yangmingshan, Puli).

Distribution: Japan (Hachijo Isl., Shikoku, Kyushu, Ryukyus), Taiwan.

Note: This species is considerably variable in the hairy markings ; namely, in specimens with well-defined greyish patches (fig. 1), the pronotum has well-defined median and lateral stripes on the brown ground, which are usually interrupted, and the patches on the alternate intervals, the humeral area and the apex of elytra are covered with greyish hairs; in brownish specimens, the hairy patches on the upperside are much more brownish, ill-defined and smaller.

Exillis japonicola is similar to longicornis Pascoe, luteus Jordan, carinatus Jordan, laticeps Jordan and impunctatus Wolfrum in the hairy markings. E. longicornis was described by female and redescribed by Jordan (1925) as “.., segment
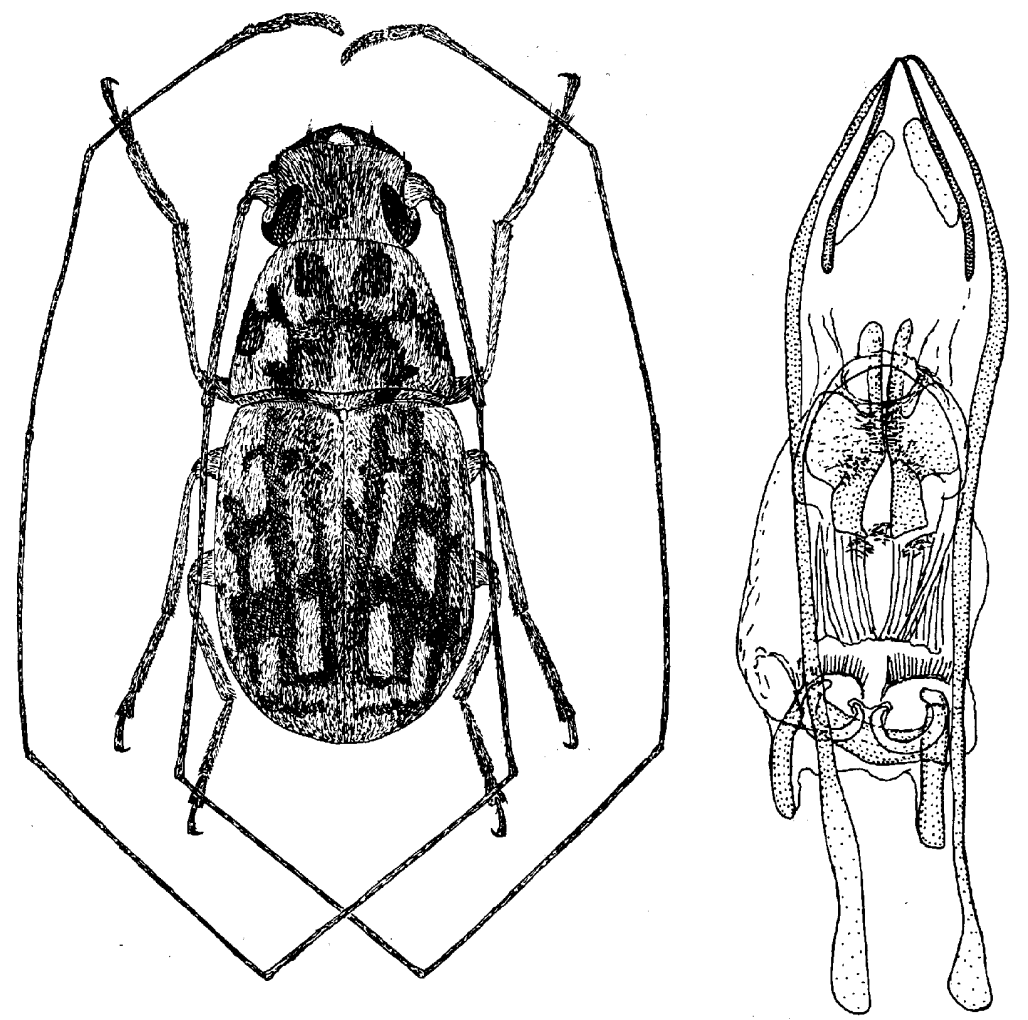

Fig. 1. Exillis japonicola, male and penis. 
3 of antenna in o nearly as long as 4 (but thicker), and in of somewhat longer than 4", but the holotype ( o ) has the 3rd segment which is a little shorter than 4 th and many males determined by Jordan as longicornis have longer 4 th segments.

The measurements of antennae of Exillis spp. by the author are as follows :

\begin{tabular}{lccclll}
\multicolumn{1}{c}{ Species } & Sex & Length of antennal & segments & $(\mathrm{mm})$ & Note \\
longicornis & 우 & $\mathbf{0 . 8}$ & $\mathbf{0 . 9}$ & $\mathbf{0 . 9 7}$ & $\mathbf{0 . 8 7}$ & Holotype \\
longicornis & $\varnothing$ & 1.1 & 2.7 & 2.1 & 2.2 & Sarawak \\
luteus & $\varnothing$ & 0.8 & 1.11 & 1.08 & 1.08 & Holotype \\
carinatus & $\varnothing$ & $\mathbf{0 . 9}$ & 3.3 & 3.4 & 3.4 & Holotype \\
laticeps & $\varnothing$ & 1.2 & 4.0 & 3.8 & 4.0 & Holotype \\
impunctatus & $\varnothing$ & $\mathbf{1 . 1}$ & 1.8 & 2.1 & 2.25 & \\
lepidus & $\varnothing$ & $\mathbf{0 . 9}$ & $\mathbf{1 . 5}$ & 1.2 & 1.15 &
\end{tabular}

They are classified into two groups by the relative length of antenna1 segments.

Fourth segment more than twice as long as 3rd longicornis, carinatus and laticeps

Fourth segment less than twice as long as 3rd lepidus, impunctatus, luteus and japonicola

Exillis horni Jordan and asper Jordan are different from the above mentioned species by the presence of large black patches on elytra. New Zealand species, variabilis Sharp and lawsoni Sharp, are now placed in Exillis, but need revision in their systematic position.

Key to SPEcies of the GENUS Exillis Pascoe based on male

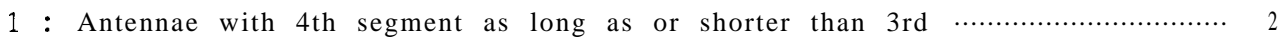

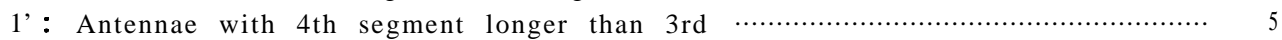

2 : Lateral prothoracic carina very short …............................. horni Jordan, 1902

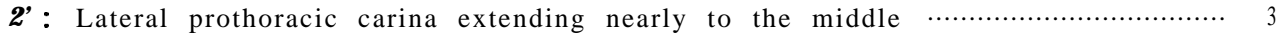

3 : Rostrum with a pair of carinae ............................................ Iawsoni Sharp, 1873

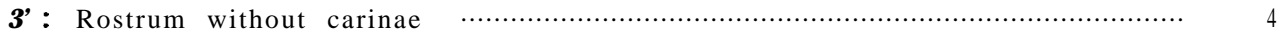

4 : Pronotum broadest at the base ................................... asper Jordan, 1925

$4^{\prime}$ : Pronotum broadest at the middle ….............................. variabilis Sharp, 1873

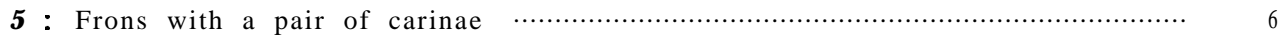

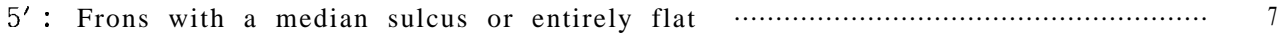

6 : Antennae with 4th segment three times as long as 3rd; frons with a distinct carina on each side along dorsal margin of eye …...............carinatus Jordan, 1925

6' : Antennae with 4th segment 1.5 times as long as 3 rd; frons with a indistinct carina on each side …................................ impunctatus Wolfrum, 1924

7 : Antennae with 4 th segment more than twice as long as 3 rd, apex of 4 th segment exceeding far beyond elytra 
7': Antennae with 4th segment less than twice as long as 3rd, apex of 4th seg-

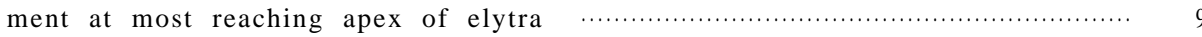

8 : Antennae with 4th, 5th and 6th segments subequal in length ... laticeps Jordan, 1925

8': Antennae with 4th segment distinctly longer than 5th, the latter equal to

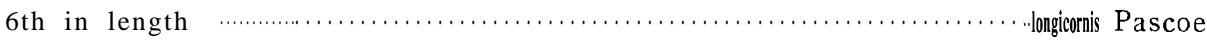

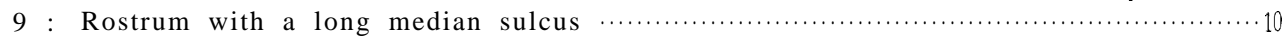

9': Rostrum with a short, punctiform median sulcus; antennae with 4th segment

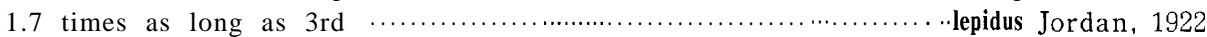

10 : Antennae with 4th segment about 1.4 times as long as 3rd, anterior margin of rostrum straightly truncate ….............................. luteus Jordan, 1925

$10^{\prime}$ : Antennae with 4th segment 1.7-1. 9 times as long as 3rd; anterior margin of rostrum concave at middle $\ldots \ldots \ldots \ldots \ldots \ldots \ldots \ldots \ldots \ldots \ldots \ldots \ldots$ japonicola Nakane, 1963

\section{Platystomos Schneider}

Platystomos Schneider, N. Mag. Liebh. Ent., I (1) : 21, 1791 (Type : Curculio albinus Linnaeus, 1758).

Platystomus Hellwig (in litt.), Schneider, N. Mag. Lirbh. Ent., IV: 393, 1792.

Macrocephalus Olivier, Intr. Hist. Nat. Ins., 4 (3) : 36, 1789 (preoccupied by Swederus, 1787).

Anthribus Fabricius (partim), Ent. Syst., I (2) : 375, 1792.

Platystomos sellatus Roelofs (Photo. A)

Anthotribus (Anthribidius) sellatus Roelofs, Deut. Ent. Zschr., XXIII: 302, 1879 (Japon).

Anthribus daimio Sharp, Trans. Ent. Soc. Lond., 1891: 319, 1891 (Yokohama, Kobe, Kurigahara, Junsai).

Specimens examined: 20 examples from Hokkaido, Aomori, Fukushima, Hyogo, Hiroshima, Fukuoka, Kumamoto and Tsushima.

Distribution : Japan (Hokkaido, Honshu, Shikoku, Kyushu, Tsushima).

Platystomos asteromaculatus Oda (Photo. B)

Platystomus asteromaculatus Oda, Trans. Shikoku Ent. Soc., 14: 27, 1978 (Amami-Oshima, Yonaguni).

Specimens examined: $3 \partial^{\star}$, Mt. Yuwandake, Amami-Oshima, 30. vii. 1963, Y. Hirashima \& J. L. Gressitt leg. ; 1 ㅇ, 24-26. iv. 1974, T. Kinoshita leg. (paratype). $1{ }^{3}$ ㅇ, Nishinakama, Amami-Oshima, 24. v. 1978, H. Makihara leg. 1 ㅇ, Torigamine, Sumiyo, Amami-Oshima, 8. iv. 1977, T. Ogasawara leg. 1 우, Oku, Okinawa, 16. v. 1978, H. Makihara leg.

Distribution : Japan (Amami-Oshima, Okinawa and Yonaguni Isls.).

Note: This species is very close to sellatus Roelofs, but the setal fascicles on the pronotum and the elytra are longer and the subbasal large white patch on the elytra between $3 \mathrm{rd}$ striae expands laterally on 4 th and 5 th intervals as narrow points.

\section{Penestica Pascoe}

Penestica Pascoe, Ann. Mag. Nat. Hist., (3) IV: 332, 1859 (Type : Penestica inepta Pascoe, 1859 , by monotypy).

Pioenia Pascoe, Journ. Ent., I: 332, 1860 (Type :Pioenia saginata Pascoe, 1860, by mono- 
typy).

Penestica brevis albescens Shibata, comb. nov. (Photo. D)

Paraphloeobius brevis Jordan, Nakane, Icon. Ins. Jap. Col. Nat. Ed., II: 350, pl. 175, f. 22 (Honshu, Kyushu, Taiwan).

Paraphloeobius brevis albescens Shibata, Entom. Rev. Jap., XV : 47, pl. 6, f. 8 \& 9, 1963 (Nara : Kasuga).

Specimen examined: 1, Mt. Takachiho, Kirishima, Kagoshima Pref., 28. vi. 1959, H. Yamamoto leg,

Distribution : Japan (Honshu, Kyushu).

\section{Caenophloeobius gen. nov.}

Head and frons neither sulcate nor carinate. Scrobes foveiform, the dorsal margin carinate and prolonged downwards to the ventral face of eyes. Eyes strongly emarginate in front. Antennae slender, reaching the middle of elytra in male or to the humeri in female, 1st and 2nd segments very short, club three-segmented. Pronotum with the dorsal carina basal, rectangularly angulate at side and the lateral carina reaching anteriorly beyond the middle. Elytra arched at the base, parallel-sided or slightly widened from humeri to the middle. Femora clavate. Tibiae gently curved inwards. Tarsi slender, 1st segment slender, more than three times as long as wide, 3rd segment as broad as the 2nd. Rostrum separated from head by a deep transverse sulcus on the underside between eyes.

Type-species : Phloeomimus inconspicuus Wolfrum, 1948.

Here also belong Phloeomimus tenuipes Jordan, 1936, and Phloeobius facilis Jordan, 1931.

This new genus is very close to Phloeomimus Jordan, 1906, but separable from it by the characters noted in the following key.

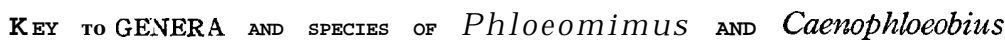

1 : Tarsi broad, 1st segment a little longer than wide and much shorter than 4 th; eyes less prominent; antennae not reaching humeri ; pronotum covered with unicoloured greyish hairs ....................Phloeomimus griseus Jordan, 1906

1': Tarsi slender, 1st segment three times as long as wide and nearly as long as or longer than 4th; eyes large, strongly convex; antennae reaching humeri in female or to the middle of elytra in male; pronotum with greyish spots on brownish general covering …............. Caenophloeobius gen, nov........ 2

2 : Antennae with 2 nd segment longer than 3rd; elytra broadly depressed at the base ............................

2': Antennae with 2nd segment shorter than 3rd

3 : Antennae with 3rd segment longer than 4th

Caenophloeobius inconspicuus (Wolfrum, 1948), comb, nov.

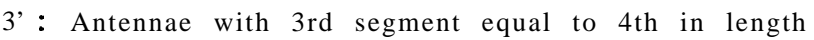

Caenophloeobius facilis (Jordan, 1931), comb. nov. 


\section{K. MORIMOTO}

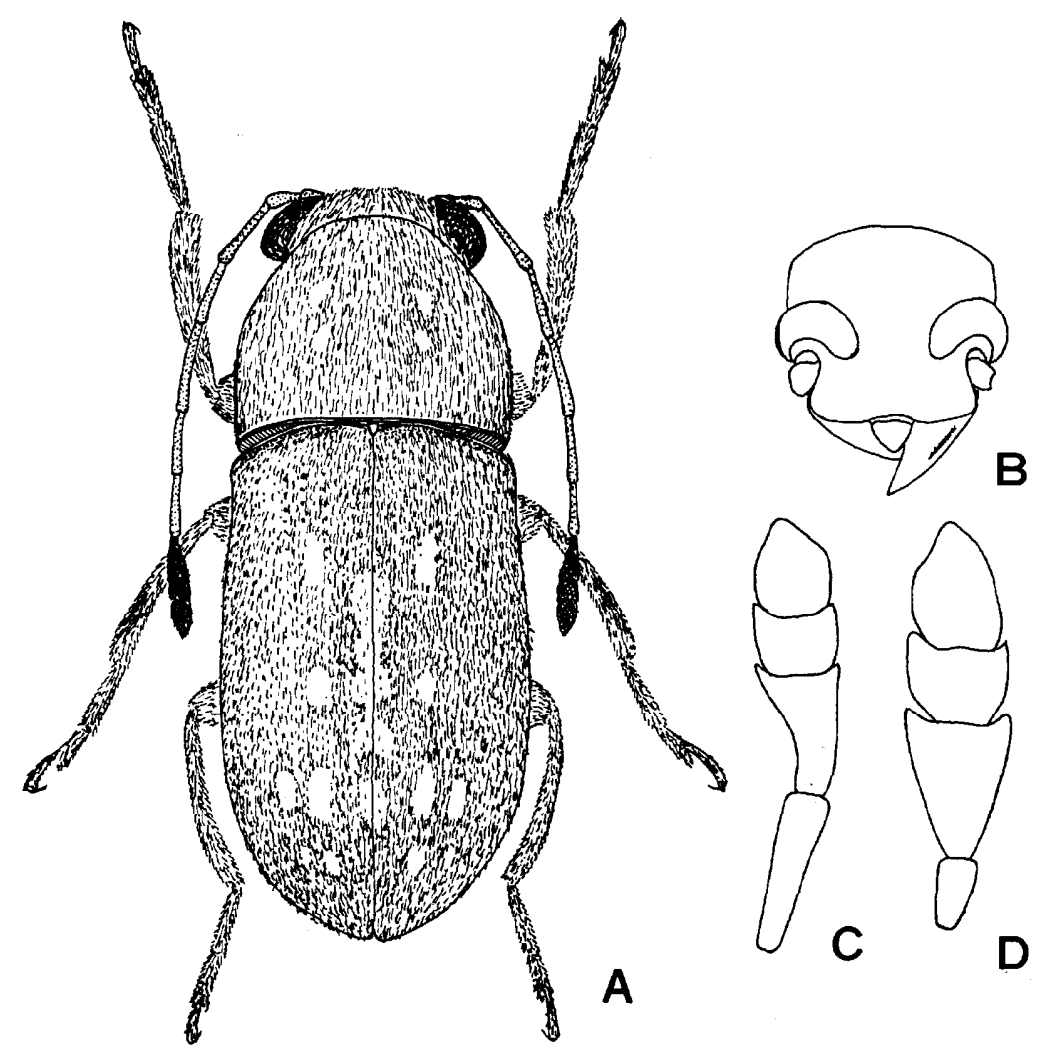

Fig. 2. Caenophloeobius inconspicuus. A: Male. B: Head, male. C: Antenna1 club, male. D: Ditto, female.

Caenophloeobius inconspicuus Wolfrum, comb. nov. (Photo. C; Fig. 2)

Phloeomimus inconspicuus Wolfrum,Ent., Blätt. XVL-XLIV : 146, 1948. (China: Fukien).

Phloeobius planus Shibata, Entom. Rev. Japan, XV: 46, 1963. (Is. Amami-Oshima, ठ); Oda, Shikoku Chuho, 22: 114, 1977. (Kurinodake). -syn. nov.

Specimens examined: 1 우, Sungkang, Nantou Hs., Taiwan, 14. vii. 1966, H. Sasaji leg. 1 ㅇ, Tihyuehtan, Nantou Hs., Taiwan, 15. vii. 1966, H. Sasaji leg. 1 으, Fenchihu, Chiai Hs., Taiwan, 22. vii. 1966, H. Sasaji leg. $1 \overbrace{}^{\Uparrow}$, Yangmingshan, Taipei Hs., Taiwan, 24. viii. 1966, H. Sasaji leg. $1 \precsim$, Nishinakama, AmamiOshima, 25. v. 1978, H. Makihara leg.

Distribution : Japan (Kyushu, Is. Amami-Oshima), Taiwan, China (Fukien).

\section{Phloeobius Schoenherr}

Phloeobius Schoenherr, Curc. Disp. Meth., : 36, 1826 (as subgenus of Anthribus Fabr.;

Type : Anthribus griseus Fabricius, 1792 = gigas Fabricius, 1775).

Phloeobius alternanus Wiedemann (Fig. 3, H-J)

Anthribus alternanus Wiedemann, Zool. Mag., I (3) : 172, 1816 (Bengal).

Anthribus apicalis Walker, Ann. Mag. Nat. Hist., (3) III: 262, 1859 (Ceylon) ; Sharp, Trans. 
Ent. Soc. London, 1891: 319, 1891 (Japan).

Phloeobius gigas, Matsumura (nec Fabricius), 6000 111. Ins. Jap. Emp.,: 273, no. 866, 1931;

Kato, Three Col. Ill. Ins. Jap., IX: pl. 29, f. 9, 1931.

Specimens examined: 10 , Akita, 7. vii. 1912, E. Hori leg. 1 , Tokyo, 14. v. 1935, I. Maeda leg. 1 우, Kuraru, Taiwan, 3. ix. 1921, T. Esaki leg. 1 우, Taiwan, 16. vi. 1967, Chang leg.

Distribution : Japan (Honshu, Kyushu), Taiwan, Indochina, Sumatra, India, Ceylon.

Note: This species has often been recorded by Japanese entomologists as gigas, but the latter has the slightly dilated 3rd segment of the tarsi and the rostrum is separated from the head by a transverse sulcus on the underside between the eyes.

Phloeobius gibbosus Roelofs (Photo. F; Fig. 3, E-G)

Phloeobius gibbosus Roelofs, Ann. Soc. Ent. Belg., XXII, Compt. Rend. :1v, 1879 (Japon).

Specimens examined: 29 examples from Kyoto, Osaka, Okayama, Fukuoka, Kumamoto and Kagoshima Prefs.

Distribution : Japan (Honshu, Shikoku, Kyushu, Is. Tanegashima).

Phloeobius mimes Sharp (Photos. G, H; Fig. 3, A-D)

Phloeobius mimes Sharp, Trans. Ent. Soc. London, 1891: 319, 1891 (Nagasaki).

Specimens examined: Type ( ) and paratypes ( $1 \circlearrowleft 1 \%)$, Nagasaki, Lewis leg. [in the British Museum (Natural History)].

Distribution : Japan (Kyushu).

Note: Oda (1977) considered that P.mimes might be a dwarf form of gib-
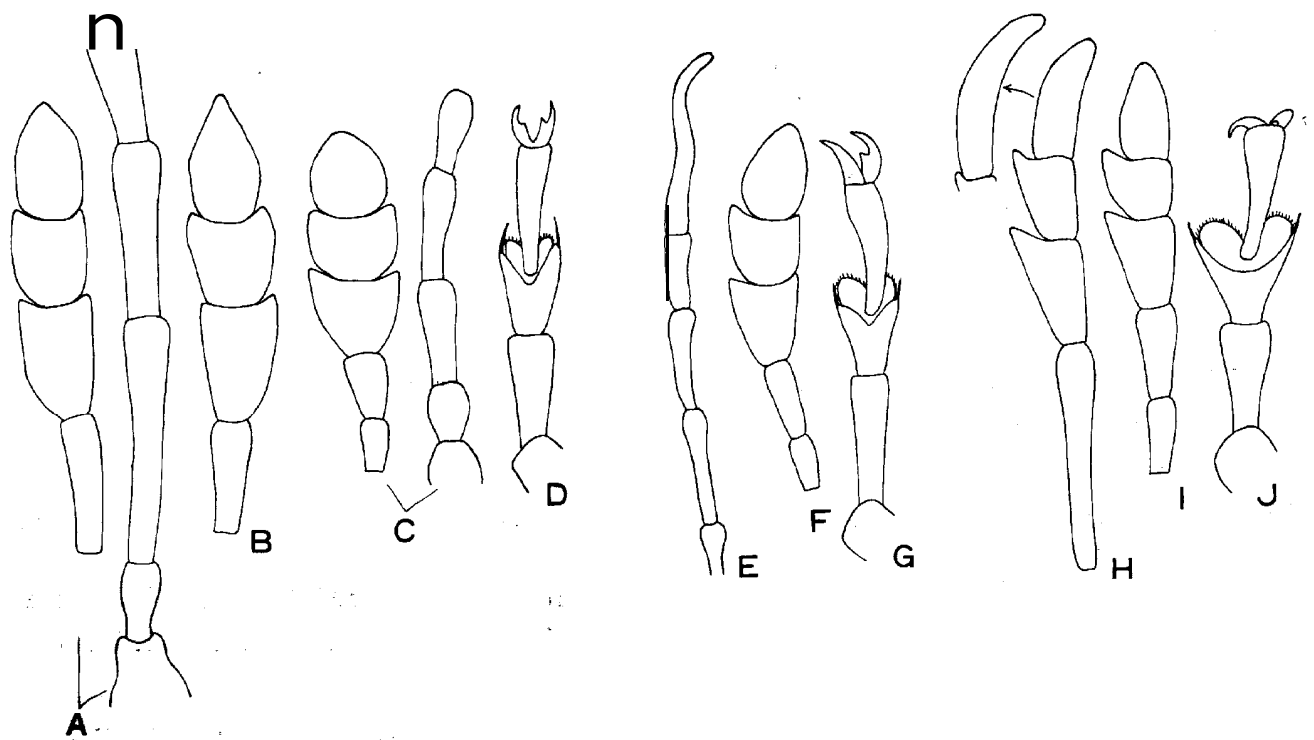

Fig. 3. Antenna and right front tarsus of Phloeobius spp. A-D: mimes (A, D: Holotype, male. B: Paratype, male. C: Paratype, female). E-G: gibbosus (E, G: Holotype, male. $\mathrm{F}$ : Paratype, female). H- J : alternanus (H : male. I-J: Holotype of apicalis, female). 
bosus, but they are distinct species and clearly separable to each other by the characters noted in the following key.

Phloeobius stenus Jordan (Photo. E)

Phloeobius stenus Jordan, Nov. Zool., XXX: 173, 1923 (Shanghai).

Phloeobius stenoides Shibata, Entom. Rev. Japan, XV: 45, 1963 (Osaka: Mt. Iwawaki ; Kyoto:

Hanase). -syn. nov.

Specimens examined: $1 \precsim 1$ ㅇ, Mt. Kiyosumi, Chiba Pref., 8. vi. 1963, K. Morimoto leg. 16, Mt. Hiko, Fukuoka Pref., 5. viii. 1955, S. Nakao leg. ; $1 \precsim$, 8-10. v. 1957, K. Morimoto leg. 1 우, Tatsudayama, Kumamoto City, 16. v. 1975, A. Iwasaki leg. 1 우, Mt. Omoto, Ishigaki, 29. v. 1976, T. Ogasawara leg.

Distribution : Japan (Mikura Isl., Honshu, Shikoku, Kyushu, Ishigaki Isl.), China (Shanghai).

Key to Japanese spectes of Phloeobius

1 : Underside of head with a transverse sulcus separating rostrum from head; terminal segment of antennae usually slender and bisinuate in male, antennal club in female slightly asymmetrical and more strongly dilated internally gibbosus Roelof $\mathrm{s}$

$1^{\prime}$ : Underside of head without such sulcus

2 : Tarsi with the 2nd segment triangularly dilated and the anterior margin deeply and roundly concave for the reception of broad $3 \mathrm{rd}$ segment …............. 3

2': Tarsi with the 2nd segment weakly dilated and the anterior margin triangularly notched for the reception of smaller 3rd segment; terminal segment of antennae shorter than 9th

3 : Elytra more strongly convex behind the base between suture and 4th stria, greyish with brown spots on alternate intervals. $12-15 \mathrm{~m} \mathrm{~m}$.... alternanus Wiedemann

3': Elytra weakly convex behind the base between 1 st and 5 th striae, the sutural area much spotted with blackish, rather strongly contrasting with the lateral area, which is not spotted with blackish, but with greyish white in alternate intervals, the dark area continued laterad in front of the grey apical patch. 8-11. $5 \mathrm{~mm}$

stenus Jordan

Illis Jordan

Illis Jordan, Novit. Zool., XXXIX : 319, 1936 (Type : Illis rusia Jordan, 1936, by original designation).

Illis anna Shibata (Fig. 4)

Illis anna Shibata, Entom. Rev. Japan, XXII: 24, 1969 (Ishigaki: Mt. Omoto ; Is. Tane ; Is. Kuchinoerabu).

Specimens examined: 75 examples from Kuchinoshima, Ishigaki and Iriomote Islands. 1 ㅇ, Lushan, Wenchuan, Nantou Hs., Taiwan, 7. vi. 1976, H. Makihara leg.

Distribution : Japan (Yakushima, Tanegashima, Nakanoshima, Kuchinoerabu, Amami-Oshima, Ishigaki and Iriomote Islands), Taiwan.

Note: This species is close to rusia Jordan, 1936, and medana Jordan, 1936, 


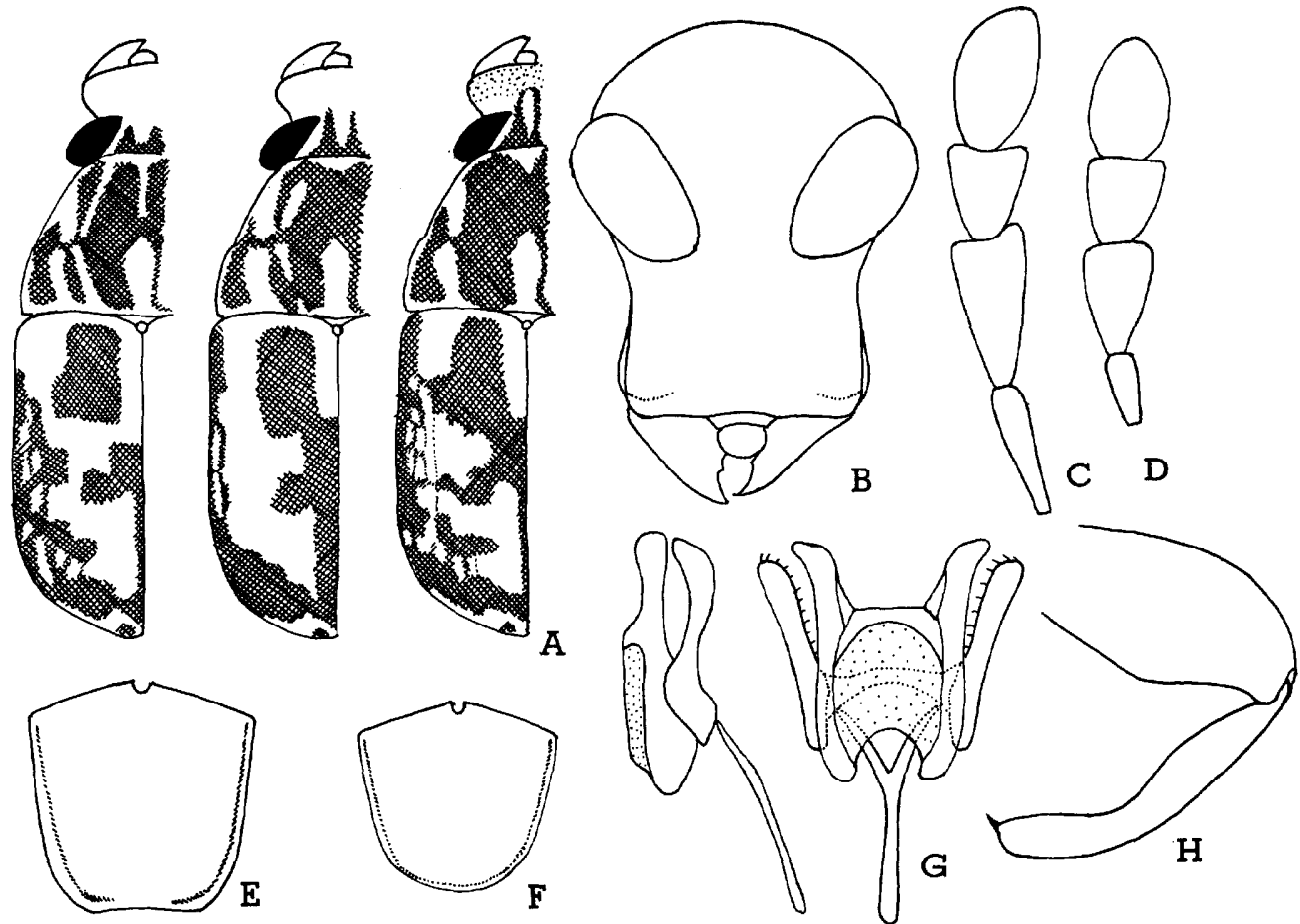

Fig. 4. Illis anna (A: Hairy pattern. B: Male head. C: Antennal club, male. D: Ditto, female. E: Male pygidium. F: Ditto, female. G: Genital segment, dorsal and lateral aspects. H: Middle leg, male.

but easily separable from them by the strongly curved median tibiae and the subquadrate pygidium in male.

\section{Tribe MecocerinI}

Mecocerides Lacordaire, Gen. Col., VII: 493, 1866.

Mecocerini Morimoto, Bull. Gov. Forest Exp. Sta., 246: 40, 1972.

\section{Mecotropis Lacordaire}

Mecotropis Lacordaire, Gen. Col., VII: 495, 1866 (Type : Mecotropis bipunctatus Lacordaire, 1866 , by original designation).

Mecotropis ogasawarai sp. nov. (Photos. I-J; Fig. 5)

Male: Black, clothed with greyish, black and dark brown pubescence. Rostrum with median groove extending onto frons. Anterior margin of eyes straight.

Rostrum a little longer than wide, median groove continued as a narrow channel across fovea between eyes onto vertex, lateral carina which runs from anterior margin of rostrum to the dorsal margin of eye distinct; median 


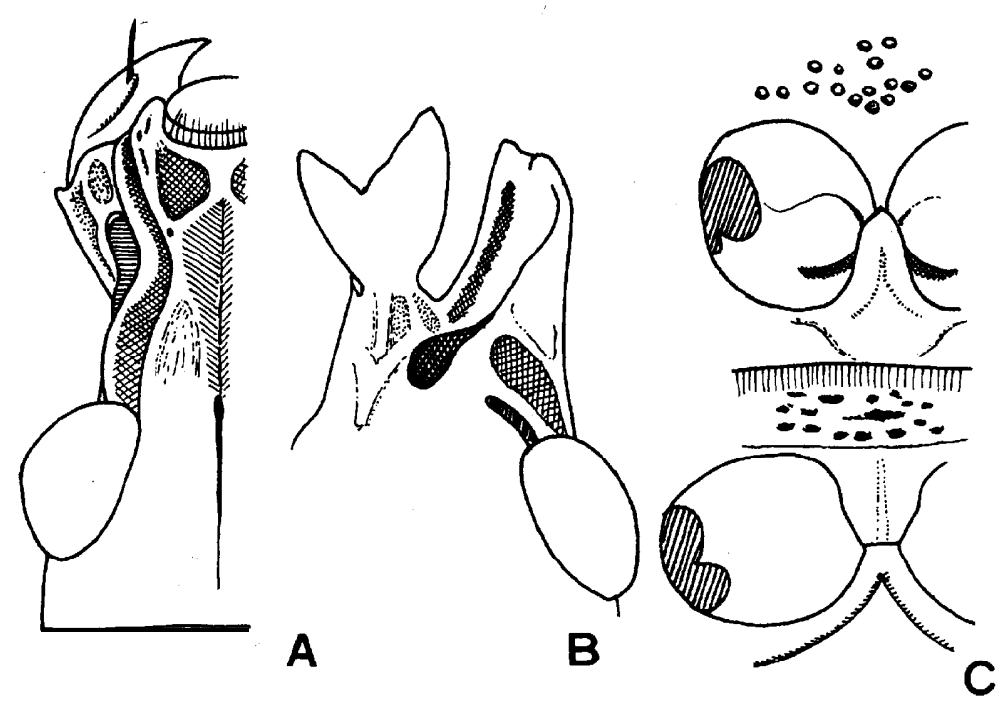

Fig. 5. Mecotropis ogasawarai, male (A: Head. B: Ditto, latero-ventral aspect. C: Proand mesosternum).

carina before the interantennal elevation between lateral carinae sharp separating rather distinct depressions ; dorso-marginal carina of antenna1 groove running posteriorly to the middle of eye; deep subventral sulcus running antero-ventrally from antero-ventral margin of eye very deep; ventral foveae very deep; labiophore rugosely punctate, marginate with shallow sulcus ; greyish pubescence covering the upperside of rostrum and forming a broad median and narrow lateral stripes on head and denser around eyes. Antennae 2.5 times as long as body, 1st and 2nd segments and apices of 3rd to 8th segments closely covered with greyish pubescence, with proportions from basal to terminal segments in length $12: 8: 31: 36: 45: 56: 70: 74: 55: 8: 15$, 1st segment clavate.

Pronotum as long as wide, broadest at the middle, transverse sulcus along anterior margin obsolete at the middle, wrinkled obliquely before carina, rugosely punctate behind carina, greyish pubescence forming a broad median stripe in entire length and a pair of narrower lateral stripes behind carina.

Scutellum grey, as long as wide.

Elytra 1.8 times as long as wide, greyish pubescence forming a large cruciferous patch at base and a cordiform patch on declivity, alternate intervals with small black spots, lateral area black mixing with dark brown pubescence, basal sulcus running transversely along the basal margin from scutellum and continued with tenth stria across humerus.

Pygidium as long as wide, slightly narrowing posteriorly and subtruncate at apex, greyish variegated with black.

Prosternum with a pair of oblique groove on each side, with large punctures before coxae, the punctures connate and forming transverse groove along 
anterior margin of coxae. Mesosternal process narrowly truncate at apex, with a fine median keel. Abdomen with two rows of indistinct irregular black spots on each side, the lateral spots usually larger and more distinct.

Tibiae black with greyish subapical and basal rings. Tarsi black, 1st segment grey excepting blackish basal area, 2nd segment with several greyish hairs on each side at the base, 4 th segment greyish excepting apex.

Female: Antennae reaching humeri, with proportions in length $7: 6: 7: 9$ : $9: 8: 9: 8: 10: 7: 10$. Pronotum a little broader than long. Pygidium rounded at apex.

Length : 15-22 mm. (to the apex of rostrum), 12.7-16 mm. (excluding head).

Holotype ${ }^{\rightarrow}$ (Type No. 2146, Kyushu Univ.), Oku, Okinawa, 17. v. 1978, H. Makihara leg.

Paratypes: $1 \precsim$, same locality as type, 17. v. 1977, T. Ogasawara leg. 1 우 same locality as type, 6. vii. 1978, K. Oshima leg. 1 우, Nishimedake, Okinawa, 5. vii. 1978, K. Oshima leg. 1 오, Yona, Okinawa, 19. v. 1978, H. Makihara leg.

Distribution : Japan (Okinawa Isl.).

Note: A specimen from Yona has more greyish pubescence on the upperside and the elytra are greyish between the 5th striae excepting black small spots on the alternate intervals and the basal area. (Photo. J)

This beautiful weevil is characteristic in having the robust body form and distinct markings on elytra.

Mecotropis kyushuensis Nakane (Photo. K)

Mecocerus kyushuensis Nakane, Fragm. Col., 8: 31, 1963 (Mt. Kirishima, ㅇ); Nakane, Icon. Ins. Jap., II: 351, pl. 176, f. 3, 1963 (Kyushu).

Mecotropis kyushuensis, Shibata, Entom. Rev. Japan, XXII: 9, pl. 2, f. 1 \& 4, 1968 (Is. Okinawa; Is. Amami, Is. Yaku, Is. Tane. Southern Kyushu).

Specimens examined: 1 ð 1 ㅇ, Cape Sata, Kagoshima Pref., 28. v. 1967, H. Makihara leg.; 1 đ, 18. v., Y. Miyake leg. 1우, Mt. Sannousan, Got\& Nagasaki Pref., 8. vii. 1978, M. Ezima leg. 16, Nakanoshima, Tokara Isls., 24. vii. 1964, S. Ohga leg. 1 ㅇ, Mt. Yuwandake, Amami-Oshima, 16-18. vii. 1973, C. M. Yoshimoto leg.

Distribution : Japan (Goto Isls., Kagoshima Pref., Yakushima, Tanegashima, Amami-Oshima and Okinawa Islands).

Mecotropis unoi Shibata (Photo. L)

Mecotropis unoi Shibata, Entom. Rev. Japan, XXII: 10, pl. 2, f. 2 \& 3, 1969 (Taiwan, Okinawa).

Specimen examined: 1 우, Chi-chia-wan, Mt. Hsiieh Shan, Taitung Hs., Taiwan, 20. vi. 1961, S. Uéno leg.

Distribution : Japan (Okinawa Isl.), Taiwan.

Tribe XYiINAdinI

Xylinadides Lacordaire, Gen. Col., VII: 560, 1866.

Xylinadini Morimoto, Bull. Gov. Forest Exp. Sta., 246: 43, 1972. 


\section{Xylinada Berthold}

Xylinada Berthold, in Latreille, Nat. Fam. Thierreichs: 380, 1827.

Xylinades Gyllenhal, Gen. Curc, I : 177, 1833 (Type : Xylinades westermanni Gyllenhal, 1833, by original designation).

Xylinada oshimai sp. nov. (Photo. M; Fig. 6, A)

Reddish brown to dark reddish brown; derm covered with brownish, greyish to ochreous grey and black hairs.

Head between eyes coarsely punctate, flat, without median carina, almost impunctate behind eyes and the underside; rostrum at the margin of apical sinus slightly elevated, from its middle extends a short median carina, median groove deep and shortly bifurcate behind, lateral carina deeper at the side of antenna1 socket and shallower towards apex. Underside of rostrum sharply separated from head by a transverse groove, strongly punctate. Antennae with proportions in length/width $11 / 11: 13 / 10: 24 / 10: 24 / 11: 23 / 13: 25 / 13: 23 / 14$ : $21 / 14: 21 / 18: 10 / 17: 19 / 14$, 4 th to ultimate segments with long hairs on the underside.

Pronotum nearly as long as wide, broadest at the middle, dorsal carina nearly straight or slightly curved anteriorly towards sides and obsolete on each side, weakly notched at the center. Disc strongly punctate and tuberculate before the carina except for smooth anterior part, the tubercles much smaller than punctures, sparsely provided with indistinct shallow punctures behind carina.

Elytra parallel-sided, striae with glossy granules on interstices between punctures; intervals flat, alternate intervals with blackish spots, lst, 3rd and 5 th intervals before the middle with greyish to ochreous grey spots, the latter spots also forming vague band behind the middle, black hairs forming vague patches on 3rd to 5th and 9th to marginal intervals just behind the middle.

Pygidium a little broader than long, posterior angles broadly rounded.

Prosternum transversely or T-shapedly depressed before coxae, anterior margin of the depression carinate or swollen, lateral surface between coxae and lateral carina reticulately with large punctures. Mesosternum with a glossy flat median carina, mesosternal process longitudinally depressed at the middle. Metasternum punctate, the punctures larger towards sides, metepisternum with a row of small punctures. Abdomen sparsely provided with small punctures excepting median area, each ventrite with dark brown patches on anterior and posterior corners at side margins, suture between 4th and 5th ventrites deep.

Tibiae with median black band. Tarsi with 1st and 2nd segments longitudinally depressed at the middle, 1st segment a little longer than the apical width of tibia.

Length : 10.5-13.0 $\mathrm{mm}$ (to the apex of rostrum), or 8.9-11.1 mm (excluding head). 
Holotype ơ $^{-T y p e ~ N o . ~ 2147, ~ K y u s h u ~ U n i v .), ~ M t . ~ N i s h i m e d a k e, ~ O k i n a w a, ~} 5$. vii. 1978, K. Oshima leg.

Paratypes: $2 \gtrsim$, same data as holotype. 1ð, Yona, Okinawa, 12-17. vi. 1970,

H. Makihara leg.

Distribution : Japan (Okinawa Isl.).

This new species is easily separable from the others by the flat frons.

Xylinada japonica Sharp (Photo. 0; Fig. 6, B)

Xylinades japonicus Sharp, Trans. Ent. Soc. London, 1889: 317, 1889 (Yuyama) ; Jordan, Novit. Zool., XIX : 143, 1912 (redescription; Taiwan: Kosempo and Chip Chip).

Specimens examined: 1 ex., Mt. Ichifusa, Kumamoto Pref., 24. vii. 1970, S. Naomi leg. 1 ex., Kurino, Kagoshima Pref., 24. vii. 1978, K. Sakamoto leg. 1 ex., Ishizuka, Is. Yaku, 17. vi. 1965, A. Tanaka leg. 1 ex., Mt. Yuwan, Amami-Oshima, 22. v. 1976, Gressitt leg. 1 ex., Mt. Yonahadake, Okinawa, 22. v. 1976, T. Ogasawara leg. 1 ex., Sungkang, Nantou Hs., Taiwan, 14. vii. 1966, H. Sasaji leg.

Distribution : Japan (Southern Kyushu, Yakushima, Amami-Oshima and Okinawa Islands), Taiwan.

Xỳlinada striatifrons Jordan (Photo. N; Fig. 6, C)

Xylinades striatifrons Jordan, Stett. Ent. Zeit., LVI: 260, 1895 (Khasi Hills, Assam) ; Jordan,

Opusc. Inst. Sci. Indochine, Fn. Ent., I: 30, 31, 1923 (Key; Tonkin).

Specimen examined: $1 \precsim$, Osugidani, Mt. Oto, Nishimuro Gun, Wakayama Pref., 1. viii. 1978, M. Umemoto leg.

Distribution : Japan (Wakayama), Taiwan, Tonkin, Assam.

Note: The author examined a specimen from Taihoku, Taiwan, in the collection of the British Museum (Natural History).

\section{KeY to JAPANESE SPECIES OF Xylinada}

1 : Frons striate and carinate besides distinct median carina; dorsal carina of pronotum curved anteriorly to the sides and continued to lateral carina ............. 2

1': Frons flat, neither carinate nor striate, punctate; dorsal carina of pronotum nearly straight, not actually reaching lateral carina and weakly notched at center; antennal club three times as long as wide; pronotum strongly punc-

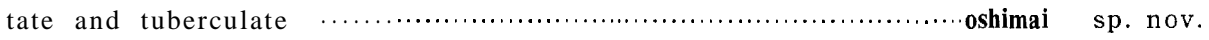

2 : Pronotum tuberculate, punctures indistinct; dorsal carina sinuate on each side and narrowly intercepted at center; elytra densely covered with glayish ochreous hairs, with blackish postmedian patches between 1 st stria and lateral margin and a common basal transverse patch between 4th striae, intervals flat, much broader than striae; antennae without long hairs, club compact, 10th segment three times as wide as long $\ldots \ldots \ldots \ldots \ldots \ldots \ldots$ japonica Sharp

$2^{\prime}$ : Pronotum punctate, not tuberculate; dorsal and lateral carinae of pronotum continuously forming an arc and narrowly intercepted at center; elytra with ill-defined postmedian patches, even intervals much narrower than odd intervals and as broad as striae, striae between punctures more or less tuberculate on dorsal and basal area; antennae with long hairs in male, 10th segment less than twice as broad as long $\ldots \ldots \ldots \ldots \ldots \ldots \ldots \ldots \ldots$ striatifrons Jordan 

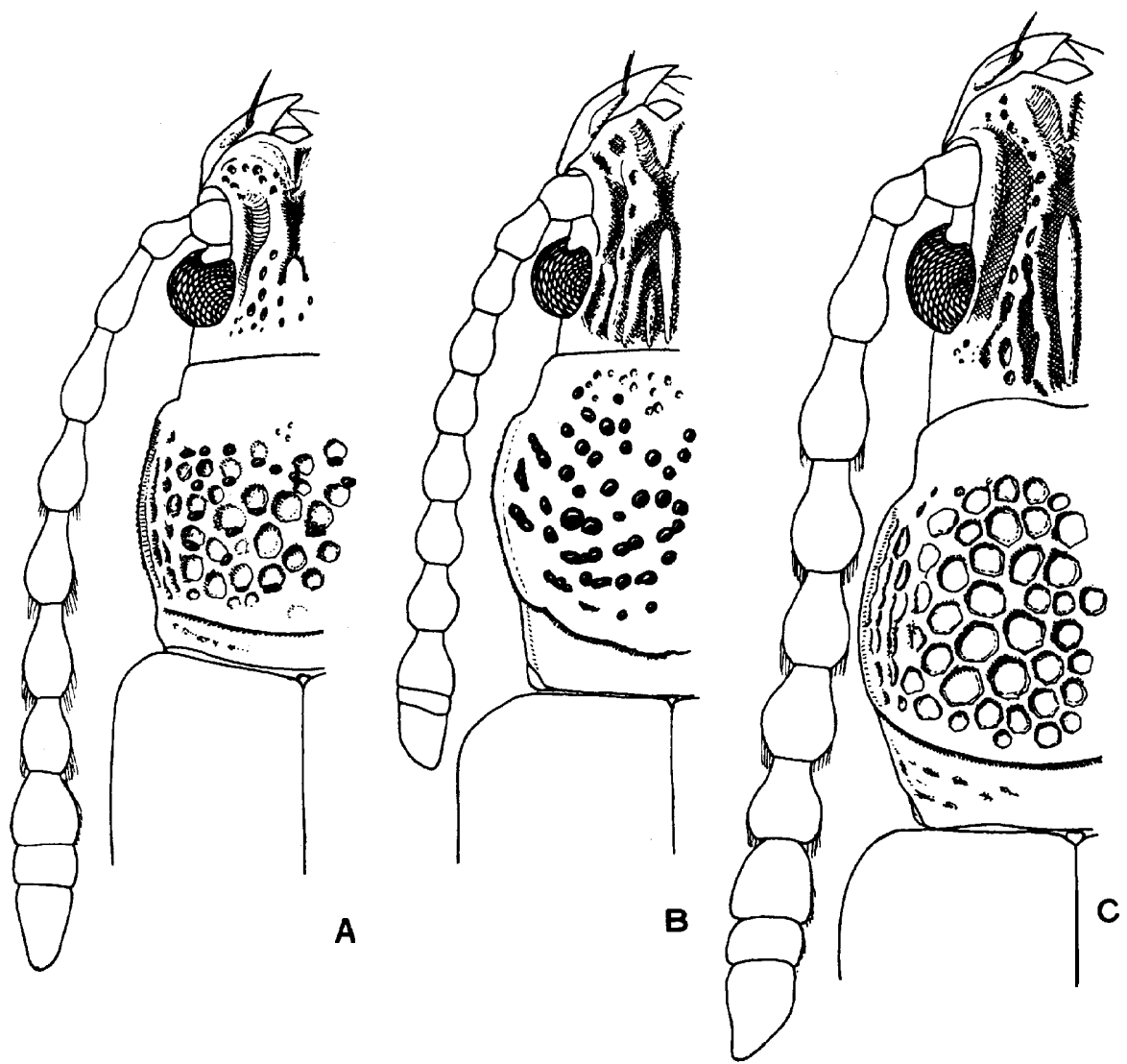

Fig. 6. Xylinada spp. (A : oshimai. B : japonica. C: striatifrons).

Stiboderes Jordan

Stiboderes Jordan, Novit. Zool., XXXII: 243, 1925 (Type : Xylinades chevrolati Ritsema, 1883, by original designation).

Stiboderes impressus stibinus Jordan (Photo. R)

Xylinades impressus stibinus Jordan, Novit. Zool., XIX: 143, 1912 (Taiwan: Hoozan, Kosempo, Fuhosho).

Stiboderes impressus stibinus, Wolfrum, Col. Cat., 102, Anthribidae : 74, 1929; Nakane, Icon. Ins. Jap. Col. Nat. Ed., II : 351, pl. 176, f. 2, 1963 (Kyushu, Yakushima).

Specimens examined: $3 \precsim$, Kagoshima Pref. 1 우, Mt. Inaodake, Kagoshima Pref., 24. vii. 1965, S. Ohga leg, $1 \precsim 1$ 우, Ohkawa Rindo, Is. Yakushima, 1-2. viii. 1974, T. Mikage leg. 1 ㅇ, Shiratani, Is. Yakushima, 26. vii. 1974, T. Mikage leg. $1 \gtrsim$, Nanshanchi, Nantou Hs., Taiwan, 16. v. 1971, K. Sakai leg. 1ð, Hungyeh Wenchuan, Hualien Hs., Taiwan, 14. vi. 1976, H. Makihara leg.

Distribution : Japan (Kagoshima, Yakushima Isl.), Taiwan. 


\section{Tribe Ecelonerini}

Ecelonerides Lacordaire, Gen. Col., VII: 562, 1866.

Ecelonerini Morimoto, Bull. Gov. Forest Exp. Sta., 246: 43, 1972.

\section{Rawasia Roelofs}

Rawasia Roelofs, Notes Leyden Mus., II: 203, 1880 (Type : Rawasia ritsemae Roelofs, 1880, by monotypy).

Rawasia ritsemae Roelofs (Photo. P; Fig. 7, A-D)

Rawasia ritsemae Roelofs, Notes Leyden Mus., II: 204, 1880 (Sumatra) ; Shibata, Entom. Rev. Japan, XXII: 33, pl. 4, f. 9, 1969 (Tokara Isls: Nakanoshima).

Eucorynus flavescens Nakane, Fragm. Col., 8: 31, 1963 (Tokara Isls: Nakanoshima) ; Nakane, Icon. Ins. Jap. Col. Nat. Ed., II: 350, pl. 175. f. 21, 1963.-syn. nov.

Rawasia flavescens, Valentine, Proc. Biol. Soc. Wash., 84: 462, 1972; Anonym, Icon. Ins. Jap., II. Addenda et corrigenda: 17, 1978.

Specimens examined: 1 오, Yona, Okinawa, 12-17. vi. 1970, H. Makihara leg. 3 守, Wushe, Nantou Hs., Taiwan, 18. v. 1971, Y. Kurosawa leg. 1 ঐ, Tanah Rata, Malaya, 30. iii. 1976, Y. Miyake leg. 18, 19 miles from Tapah, Malaya, 1. iv. 1976, Y. Miyake leg.

Distribution: India to Sumatra, China, Taiwan, Japan (Tokara Isls: Nakanoshima, Okinawa Isl.).

\section{Eucorynus Schoenherr}

Eucorynus Schoenherr, Isis von Oken, 1823 (10) : 1135, 1823 (Type: Anthribus crassicornis Fabricius, 1801, by monotypy).

Eucorynus crassicornis Fabricius (Photo. Q; Fig. 7, E-F)

Anthribus crassicornis Fabricius, Syst. Eleuth., 2: 407, 1801 (Sumatra).

Eucorynus crassicornis, Schoenherr, Isis von Oken, 1823 (10) : 1135, 1923; Shibata, Entom. Rev. Japan, XVI: 9, pl. 1, f. 10 \& 11, 1963 (Iriomote, Hainan, Cambodia). See Valentine (Proc. Biol. Soc. Wash., 84: 459-66, 1972) for synonymy.

Specimens examined: $1 \precsim$, Ishigaki, 20. v. 1962, K. Kojima leg. 1 우, Kawara, Ishigaki, 23. v. 1962, K. Kojima leg. 1ð, Yonehara, Ishigaki, 28. v. 1977, T. Ogasawara leg. $2 \delta^{\star}$, Otomi, Iriomote, 23. iv. 1969, H. Makihara leg. 31 examples from Taiwan, Thailand, Malaya and Singapore.

Distribution : Japan (Ishigaki and Iriomote Isls.), Taiwan, China, Cambodia, Thailand, Malaya, Singapore, India, Philippines, Mauritius.

\section{Dendrotrogus Jekel}

Dendrotrogus Jekel, Ins. Saunders., 1: 80, 1855 (Type: Dendrotrogús hypocrita Jekel. 1855, by original designation) ; Valentine, Proc. Biol. Soc. Wash., 84: 464, 1972.

Xenotropis Fairmaire, Bull. Soc. Ent. Fr., 1895 (12-13) CCLXXXI, 1895 (Type: Xenotropis rugicollis Fairmaire, 1895).

Dendrotrogus japonicus sp. nov. (Photo. U; Fig. 7, I-J)

Eurorynus colligens, Sharp (nec Walker), Trans. Ent. Soc. London, 1889: 318, 1889 (Higo). 

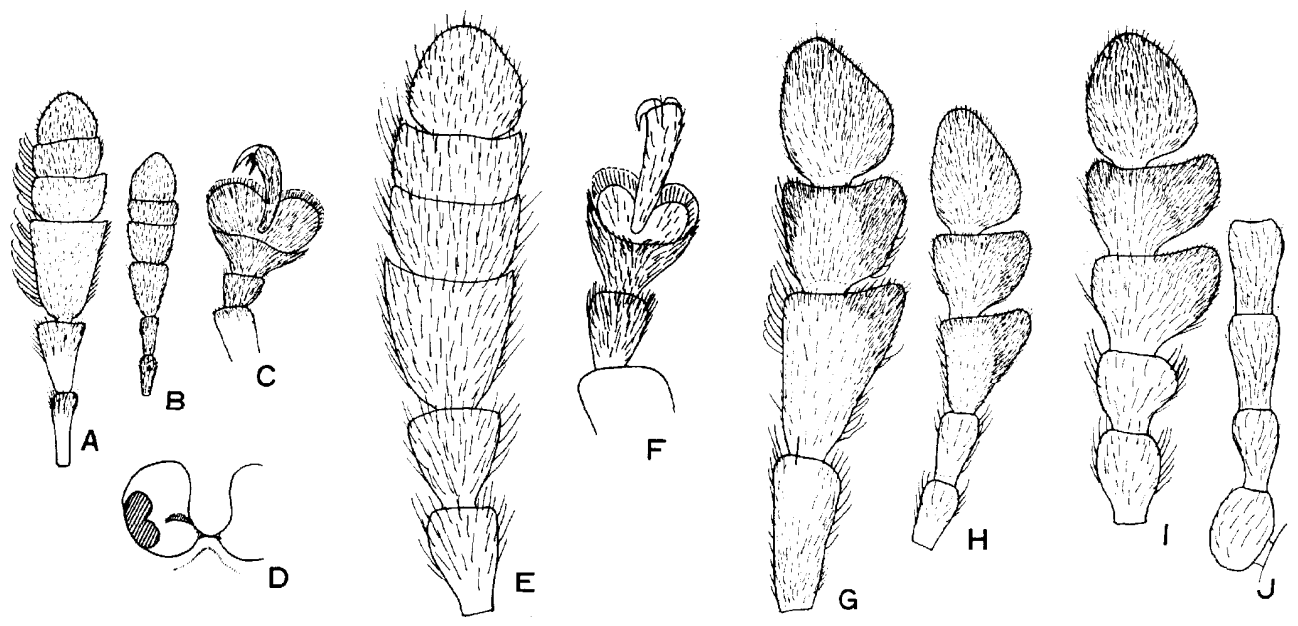

Fig. 7. A-D: Rawasia ritsemae (A: Antenna, male. B: Ditto, female. C : Right front tarsus, male. D : Mesosternal process.) E-F : Eucorynus crassicornis, male (E: Antenna. F: Right front tarsus). G-H : Dendrotrogus ohkurai (G: Antenna, male. H: Ditto, female). I -J : Dendrotrogus japonicus, male antenna.

Dendrotrogus angustipennis, Nakane (nec Jordan), Icon. Ins. Jap. Col. Nat. Ed., II: 351, pl. 176, f. 1 (Shikoku, Kyushu, Taiwan).

Male: Reddish brown to blackish brown, pronotum and elytra a little darker and variegated with paler patches, where the covering is usually greyish.

Head and rostrum with oblong punctures, which are more or less longitudinally confluent, greyish hairs on each side; rostrum parallel-sided, transverse, subtriangularly emerginate, median depression shallow, sparsely with ochreous grey hairs on each side. Antennae with proportions in length/width 9/8:9/5:9/5:10/5:9/5:9/6:9/7:9/8:12/12:9/12:14/11.

Pronotum as long as wide, broadest at the angles of carinae, dorsal carina gently arched and slightly sinuate at sides, lateral carina reaching anteriorly just behind subapical sulcus ; disk irregularly punctate, the punctures more or less transversely confluent before carina and become smaller near apical margin, weakly and transversely wrinkled punctate behind carina, with a pair of weak, longitudinal and rather broad depressions at center; greyish hairs forming indistinct patches, three along carina, two pairs just before the middle, three behind apical margin, and three behind carina.

Scutellum transverse-oval, densely covered with greyish hairs.

Elytra parallel-sided, intervals flat, striae with well defined punctures, interstices between punctures on the same plane as intervals, not granulate; blackish patches forming indistinct median band and basal conjoint band between 4th striae.

Pygidium semi-circularly rounded, 1. 5 times as wide as long, glossy, finely punctate and sparsely pubescent, visibly bare, weakly convex. 
Lateral and ventral sides of pronotum reticulately provided with large punctures before coxae. Mesosternal process subpentagonal. Metasternum with large punctures on each side, 1 st and 2 nd ventrites with several and 3rd ventrite with a few small punctures on each side, 1st and 2nd ventrites each with a transverse-oval fascicle at center, which formed of posteriorly inclined ochreous dense hairs.

Tibiae with fine dark hairs at base and the remaining major area moderately clothed with ochreous grey hairs, which are much larger than those on abdomen and as large as those on elytra.

Female: Eighth segment of antennae nearly the same shape as 7 th ; venter without hairy fascicle; pygidium subtrazepoid, flat, closely with shallow punctures.

Length : 6.8-13.9 $\mathrm{mm}$. (to the apex of rostrum), or $5.8-11.5 \mathrm{~mm}$. (excluding head).

Holotype Ђ (Type No. 2148, Kyushu Univ.), Miyanoura, Is. 'Yakushima, 29. vii. 1974, T. Mikage leg.

Paratypes: 2 ð우, same data as holotype ; 3 우, same' locality as holotype, 28. vii. 1974, T. Mikage leg. $1 \precsim$, Anbo, Is. Yakushima, 6-8. vi. 1969, H. Makihara leg. $1 \precsim$, Okawa Rindo, Is. Yakushima, 1. viii. 1974, T. Mikage leg. $1 \precsim$, Cape Sata, Kagoshima Pref., 29. v. 1952, T. Esaki \& Y. Hirashima leg. 1 , Cape Sata, Kagoshima Pref., 2-5. v. 1958, K. Morimoto leg. 10, Cape Sata, Kagoshima Pref., 1. vi. 1968. la, Cape Sata, Kagoshima Pref., 18. v. 1959, Y. Miyake leg. 1 \&, Takachiho, Kirishima, Kagoshima Pref., 24. vi. 1967.

Distribution : Japan (Kagoshima, Yakushima Isl.). Nakane (1963) recorded it from Shikoku, Kyushu and Taiwan.

Note: this species is very close to angustipennis Jordan, 1895, but separable from it by the characters noted in the key.

Dendrotrogus nagaoi sp. nov. (Photo. V; Fig. 8)

Male: Dark reddish brown to black, apices of femora and basal half of tibiae reddish brown to dark reddish brown, tarsi reddish brown to dark reddish brown; ochreous grey hairs forming ill-defined patches, tibiae with grey. ish median band.

Head densely punctate, the punctures not confluent, frons between eyes often with a fine median carina; rostrum parallel-sided, a little wider than long, with a median depression, similarly punctate as frons behind antenna1 insertions and the punctures become smaller thenceforth towards apex. Antennae with proportions in length/width $9 / 7: 9 / 4: 10 / 4: 10 / 5: 9 / 5.5: 7 / 6: 8 / 7$ : $8 / 8: 13 / 13: 9 / 13: 13 / 12$.

Pronotum as long as wide, widest at the angles of carinae, dorsal carina flat V-shaped, lateral carina weakly sinuate; disc densely punctate, the punctures large and more or less transversely confluent before carina and become smaller near apical margin, weakly and wrinkled punctate behind car- 

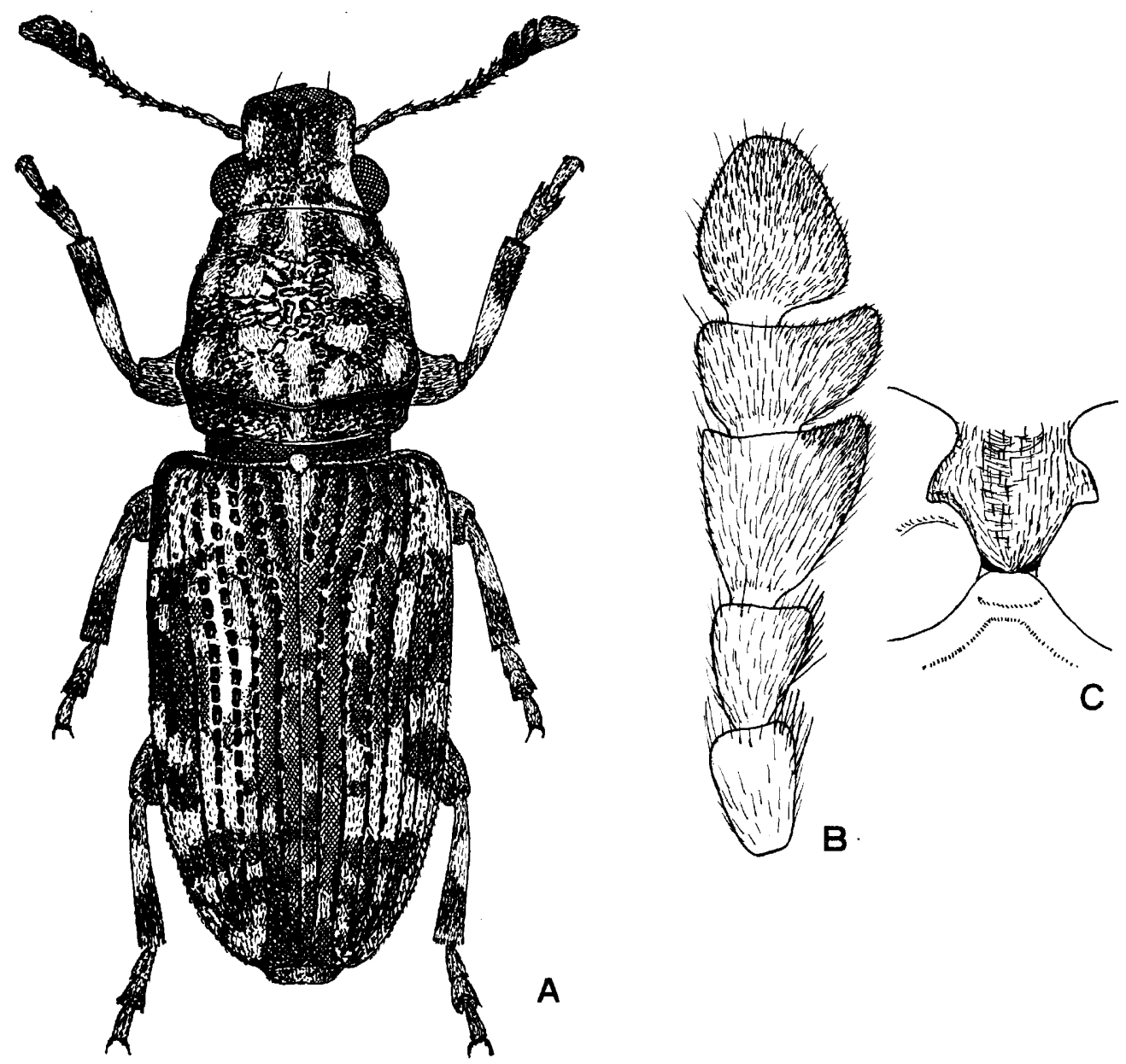

Fig. 8. Dendrotrogus nagaoi, male (A : Holotype. B: Antenna. C: Mesosternal process).

ina.

Scutellum transverse, densely covered with ochreous hairs.

Elytra parallel-sided, intervals flat, alternate intervals slightly wider, striae with well-defined punctures, not granulate; ochreous grey hairs forming illdefined patches on alternate intervals and postmedian band.

Pygidium semi-circularly rounded, 1.5 times as wide as long, convex, punctulate, ochreous hairs denser on each side.

Underside of prothorax with large punctures at side and deep punctures before coxae. Mesosternal process subpentagonal. Metasternum sparsely with large punctures at side. Venter almost impunctate, 1st ventrite with a small median fascicle, which formed of dark fine pubescence, 2nd ventrite with a trace of similar fascicle. 
Tibiae dark reddish brown to black at base and before the middle, reddish brown area between them clothed with ochreous grey hairs.

Female: Antennae shorter and robust, 8th segment slightly broader than long; venter without fascicle; pygidium weakly depressed at middle behind distal margin, punctate.

Length : 9.5-12.2 $\mathrm{mm}$ (to the apex of rostrum), or $8.0-10.9 \mathrm{~mm}$ (excluding head).

Holotype $\precsim$ (Type No. 2149, Kyushu Univ.) and Paratypes, 42 ㅇ, Azamo-Mt. Tatera, Tsushima, 10-11. vi. 1961, J. Nagao leg.

Distribution : Japan (Tsushima).

Note: This new species is very close to feae Jordan, 1895, but separable from it by the shape of dorsal carina on the pronotum, coloration of the tibiae and the presence of fascicle on the basal ventrite.

Dendrotrogus ohkurai Shibata (Photos. S, T; Fig. 7, G, H)

Dendrotrogus ohkurai Shibata, Entom. Rev. Japan, XXXI: 97, 1978. (Chichijima).

Specimens examined: 2 क, Ogiura, Chichijima, 13. vi. 1973, H. Fujita leg. 1 ఫ 1 , Mt. Chuo, Chichijima, 20. v. 1975, T. Seino leg. $23^{3}$ ㅇ, Hyogitaira, Hahajima, 6. vi. 1973, H. Fujita leg. 12 \% 10 ․ Hyogitaira, Hahajima, 7. vi. 1975, T. Seino leg.

Distribution : Japan (Ogasawara Isls.: Chichijima and Hahajima).

Note: The colour pattern of this species is characteristic among the known species of the genus and very similar to Basitropis seinoi Morimoto, 1978, from the same islands.

\section{KeY TO SPECIES OF Dendrotrogus}

1: Punctured striae with small granules between punctures on the basal area of elytra ; elytra with white patches $\ldots \ldots \ldots \ldots \ldots \ldots \ldots \ldots \ldots \ldots \ldots \ldots$ conspectus Jordan, 1923

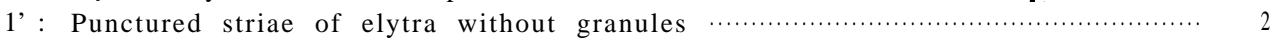

2 : Uppersurface with ochreous distinct stripes; 1 st and 2 nd ventrites each with a median fascicle, which formed of dark grey fine hairs in male. Ogasawara ISIS.

ohkurai Shibata, 1978

2': Uppersurface variegated with greyish or ochreous grey and blackish patches, blackish patches forming basal and median bands in general $\ldots \ldots \ldots \ldots \ldots \ldots \ldots \ldots \ldots . \ldots . \ldots . \ldots$

3 : Tibiae clothed with unicoloured greyish hairs excepting darker base $\ldots \ldots \ldots \ldots \ldots \ldots . . . \ldots 4$

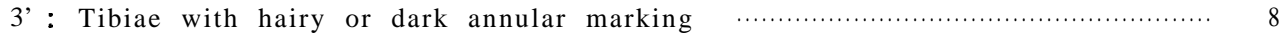

4 : Tibiae and apical half of femora closely covered with two kinds of yellowish grey hairs, smaller hairs more depressed …..................... hypocrita Jekel, 1855

4': Tibiae clothed with one kind of hairs

5 : Pronotum reticulately provided with large punctures; elytra with very strong punctured striae, 1st, 3rd and 5 th intervals much broader than 2 nd or 4 th reticulatus Jordan, 1923

5': Pronotum with more or less transversely confluent punctures

6 : Tibiae with dark patches a little before the base; head with defined punctures; 5th ventrite in male with a transverse, closely haired depression at the middle 
6': Tibiae with dark fine hairs or visibly bare at the base; 1 st and 2 nd ventrites each with a median fascicle

7 : Third ventrite with a small median fascicle in male; punctures on head not confluent; pronotum with smaller punctures ; elytra with shallower striae and broader hairs ........................................ angustipennis Jordan, 1895

7': Third ventrite without fascicle; punctures on head more or less longitudinally confluent; pronotum with larger and stronger punctures; elytra with

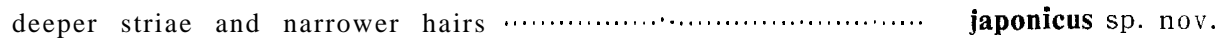

8 : Pronotum behind carina with many short transverse carina; elytra densely covered with hairs

perfolicornis Fabricius, 1801

8': Pronotum behind carina punctate; elytra sparsely covered with hairs 9

9: Dorsal carina of pronotum flat V-shaped, male first ventrite with a small median fascicle, which formed of dark fine pubescence; 2nd ventrite with a trace of fascicle; terminal margin of 5 th ventrite and pygidium each with a row of dark brown hairs; body dark brown to black, greyish hairy part on legs reddish brown, blackish band on tibiae extending almost to apex …...... .................................nagaoi sp. nov.

9': Dorsal carina of pronotum arched; male ventrite without fascicle; terminal margins of 5 th ventrite and pygidium each with a row of yellowish hairs; body reddish brown, blackish band on tibiae not reaching apex

\section{Explanation of photographs}
A. Platystomos daimio Sharp (= sellatus Roelofs), male, type ; Junsai.
B. Platystomos asteromaculatus Oda, female ; Amami-Oshima.
C. Caenophloeobius inconspicuus Wolf rum, female ; Fenchihu, Taiwan.
D. Penestica brevis albescens Shibata, female; Mt. Takachiho, Kagoshima.
E. Phloeobius stenus Jordan, male ; Mt. Hiko, Fukuoka.
F. Phloeobius gibbosus Roelofs, male, type; Nagasaki.
G. Phloeobius mimes Sharp, male, type ; Nagasaki.
H. Phloeobius mimes Sharp, female, paratye ; Nagasaki.
I - J. Mecotropis ogasawarai sp. nov., female, paratype; Okinawa.
K. Mecotropis kyushuensis Nakane, female ; Amami-Oshima.
L. Mecotropis unoi Shibata, female ; Mt. Hsiieh Shan, Taiwan.
M. Xylinada oshimai sp. nov., female, paratype; Okinawa.
N. Xylinada striatifrons Jordan, male ; Wakayama.
O. Xylinada japonica Sharp, type ; Yuyama.
P. Rawasia ritsemae Roelofs, male ; Taiwan.
Q. Eucorynus crassicornis Fabricius, female ; Malaya.
R. Stiboderes impressus stibinus Jordan, type ; Hoosan, Taiwan.
S-T. Dendrotrogus ohkurai Shibata, S: female, T: male ; Hahajima.
U.Dendrotrogus japonicus sp. nov., male, paratype; Is. Yaku.
V.Dendrotrogus nagaoi sp. nov., male, paratype; Tsushima. 

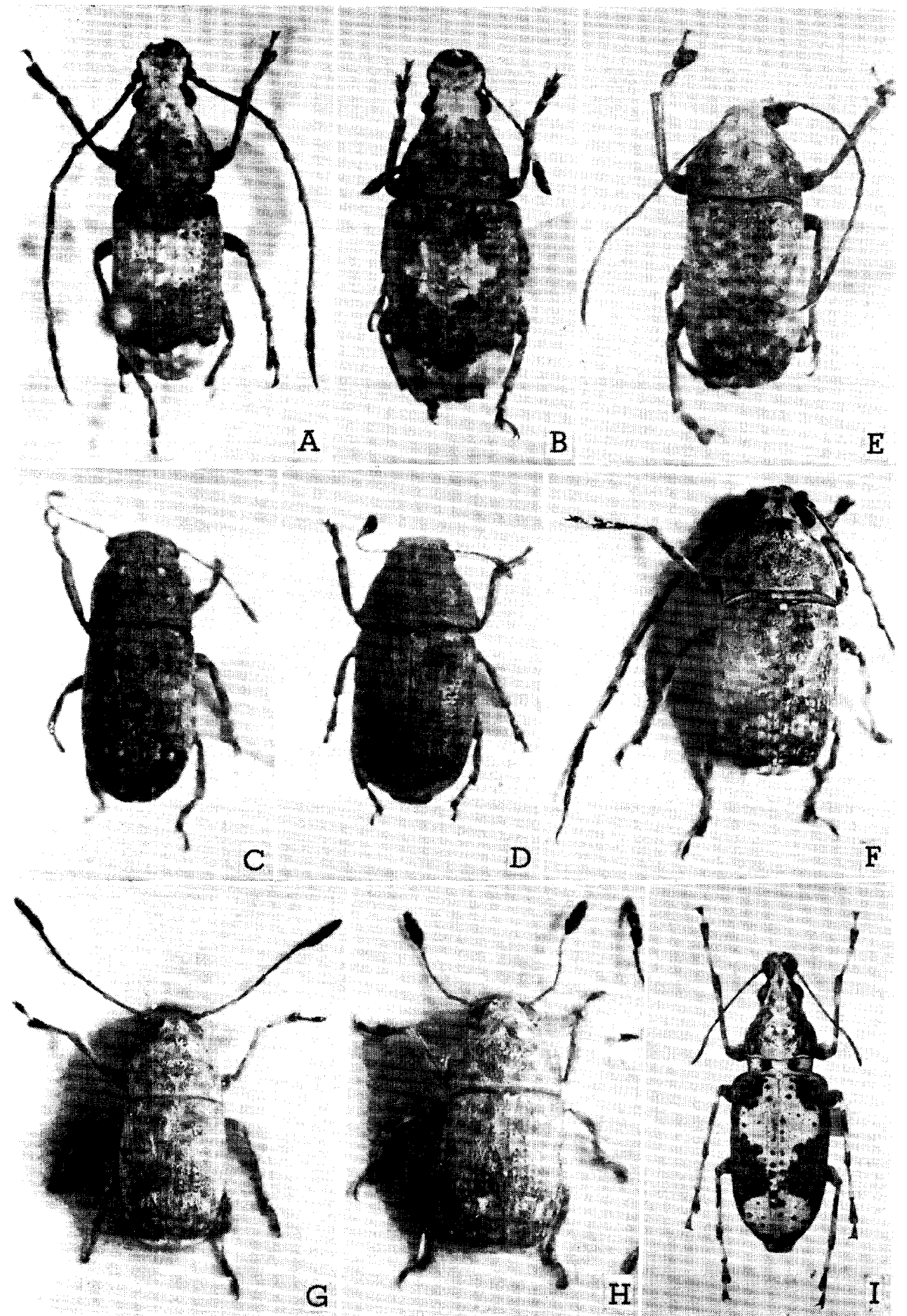


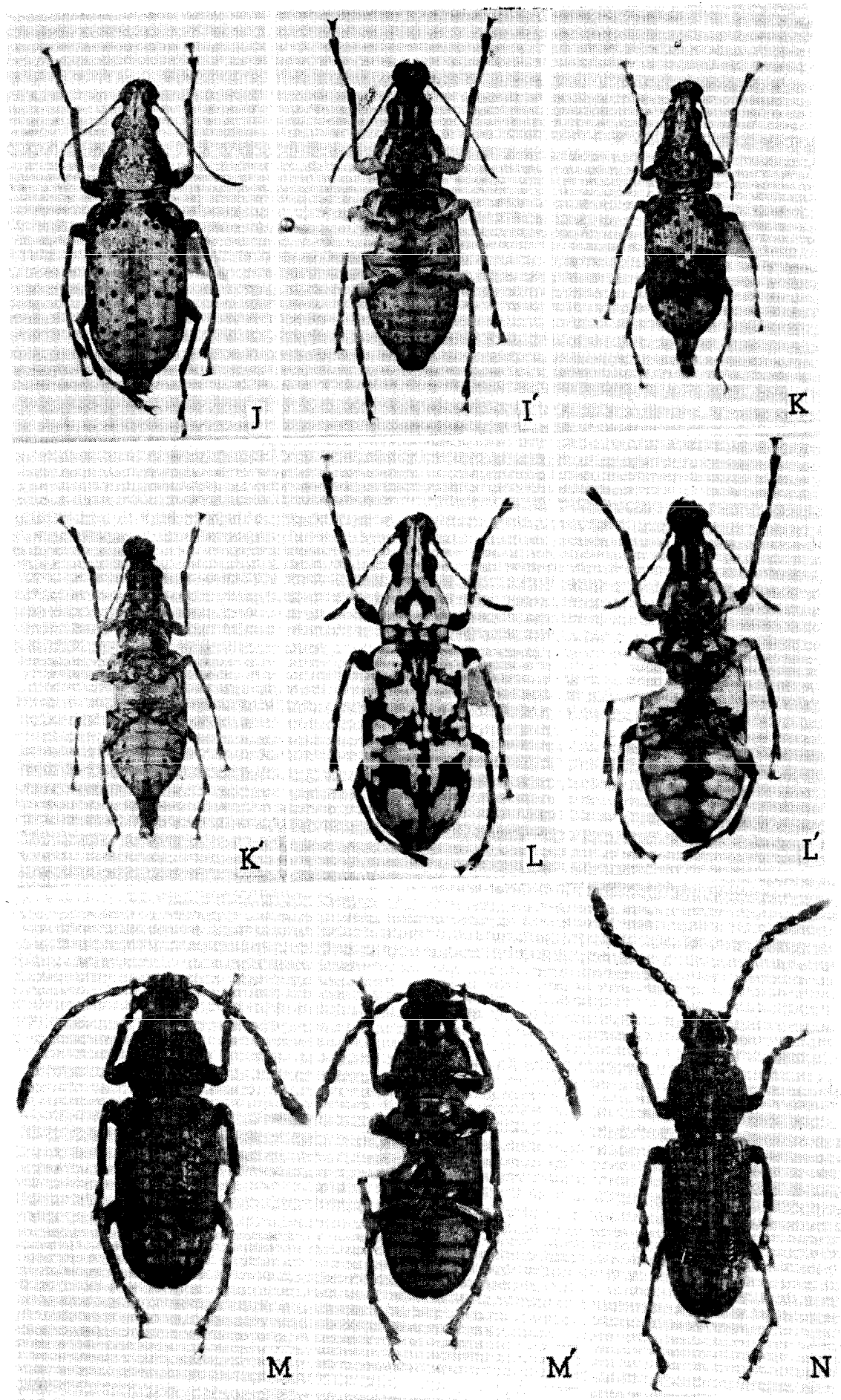


THE FAMILY ANTHRIBIDAE OF JAPAN
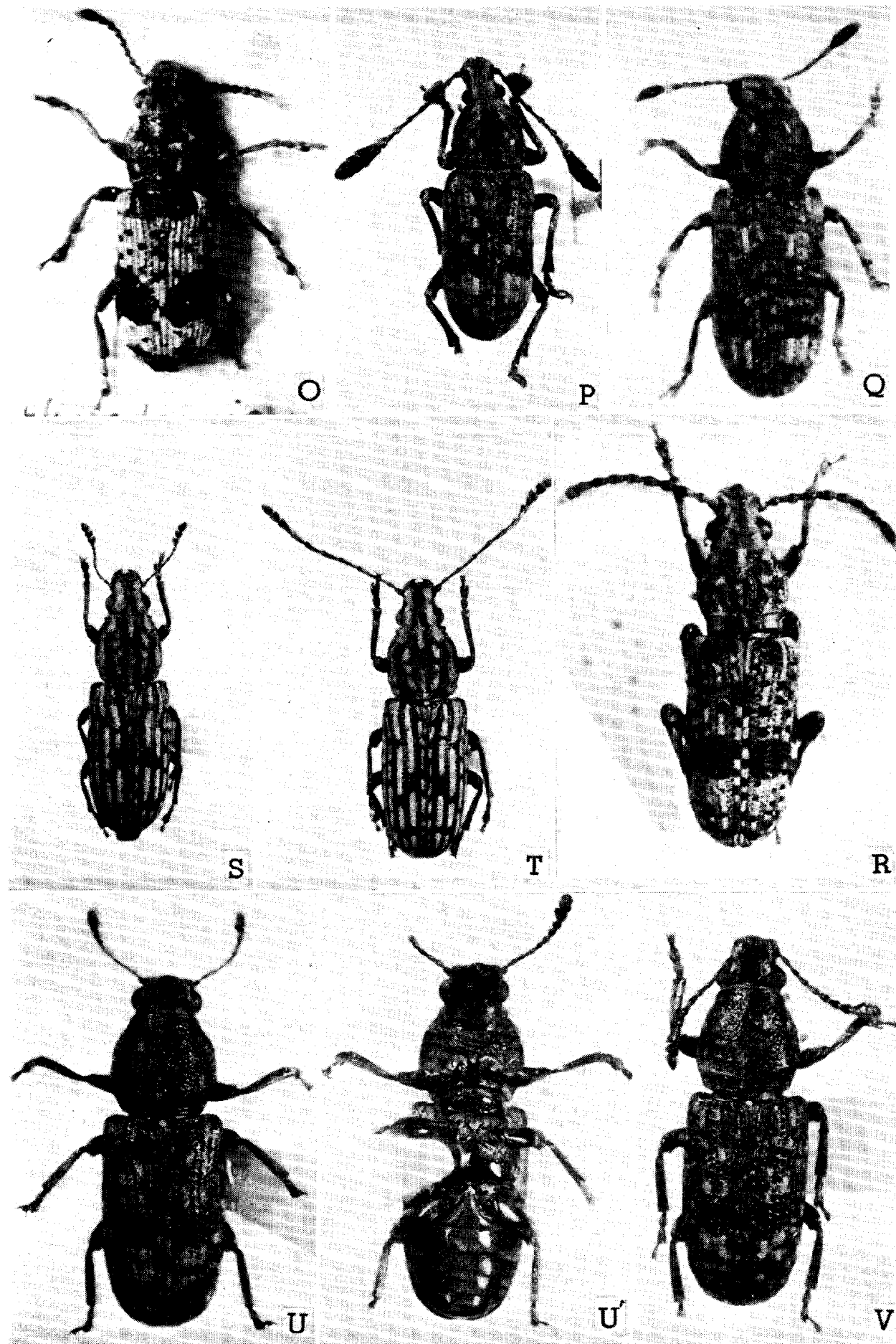